research

\title{
17-Hydroxyprogesterone Response to Standard Dose Synacthene Stımulation Test in CYP21A2 Heterozygous Carriers and Non-Carriers in Symptomatic and Asymptomatic Groups: Meta-Analyses
}

\section{Polat S and Arslan Y.K. SDSST to Determine CYP21A2 Heterozygous Mutation}

Seher Polat ${ }^{1}$, Yusuf Kemal Arslan ${ }^{2}$

${ }^{1}$ Erzincan Binali Yildirim University, Medical Faculty, Department of Medical Genetics, Erzincan/Turkey

${ }^{2}$ Erzincan Binali Yildirim University, Medical Faculty, Department of Biostatistics, Erzincan/Turkey

What is already known on this topic?

Standard dose synacthene stimulation test (SDSST) is a gold standard biochemical-screening test for evaluating adrenal gland functions. Despite the presence of the studies to determine heterozygous CYP21A2 mutation by the SDSST, the reliability of the test is still controversial.

What this study adds?

The meta-analyses were performed to determine the differences of 17-hydroxyprogesterone (17-OHP) response of the SDSST $(0.25 \mathrm{mg})$ in the diagnosis of CYP21A2 heterozygous carriers with or without clinical sign of androgen excess disorders and to give an idea about the usability of the test and the cut-off levels to be applied. The meta-analyses support the idea that the stimulated 17-OHP level had the potential to be used by SDSST to identify the CYP21A2 carriers although the basal 17-OHP level was not informative enough. Additionally, the median level of stimulated 17-OHP was higher in symptomatic mutation-free controls than in asymptomatic mutation-free healthy controls and similarly, the median level of stimulated 17-OHP was higher in symptomatic mutation carriers than in asymptomatic mutation carriers. Clinical phenotype may affect the evaluation of the test.

\begin{abstract}
Objective: Standard dose synacthene stimulation test (SDSST) is a gold standard screening test for evaluating adrenal gland functions. Despite the presence of the studies to determine heterozygosity of CYP21A2 by the SDSST, the reliability of the test is still controversial. Therefore, the meta-analyses were performed to determine the differences of the 17-hydroxyprogesterone(17$\mathrm{OHP})$ response to the standard dose $(0.25 \mathrm{mg})$ synacthene stimulation in the diagnosis of CYP21A2 heterozygous individuals with
\end{abstract} or without a clinical sign of androgen excess disorder.

Methods: PubMed and MEDLINE databases were searched. A total of 1215 subjects (heterozygous carriers n:669, mutationfree controls n:546) were included in the meta-analyses.

Results: Basal 17-OHP median-mean levels were determined to be 4.156(3.05-10.5)-5.241(2.59)nmol/L and 3.90(2.20-9.74)$4.67(2.62) \mathrm{nmol} / \mathrm{L}$ in symptomatic heterozygous carriers and symptomatic mutation-free controls, respectively. Stimulated 17OHP median-mean levels were determined to be 17.29(14.22-37.2)-19.51(7.63)nmol/L and 9.27(7.32-15.9)-10.77(3.48)nmol/L in symptomatic heterozygous carriers and symptomatic mutation-free controls, respectively. Basal 17-OHP median-mean levels were determined to be $3.21(2.64-4.78)-3.33( \pm 0.84) \mathrm{nmol} / \mathrm{L}$ and $3.12(1.82-3.6)-2.83(0.71) \mathrm{nmol} / \mathrm{L}$ in asymptomatic heterozygous carriers and asymptomatic mutation-free healthy controls, respectively. Stimulated 17-OHP median-mean levels were found to be 14.16(12.73-16.37)-14.16(1.37) $\mathrm{nmol} / \mathrm{L}$ and 6.26(4.9-8.23)-6.48(1.2)nmol/L in asymptomatic heterozygous carriers and asymptomatic mutation-free healthy controls, respectively. The cut-off levels for stimulated $17-\mathrm{OHP}$ were $10.48 \mathrm{nmol} / \mathrm{L}$ and $13.48 \mathrm{nmol} / \mathrm{L}$ for asymptomatic heterozygous and symptomatic heterozygous, respectively.

Conclusion: The meta-analyses support the idea that stimulated 17-OHP level has potential to use to determine CYP21A2 carriers. Besides, considering differences of the basal and stimulated 17-OHP levels in symptomatic heterozygous individuals than those who were asymptomatic heterozygous could increase the accuracy of the test.

Keywords: Adrenal insufficiency, Synacthene stimulation test, 17-OHP level, Heterozygous, CYP21A2

Dr. Seher Polat, Erzincan University Medical Faculty, Medical Genetics Department, Erzincan,

$+00905553942016$

polatdna@yahoo.com

0000-0003-1209-9602

05.07 .2021

02.11 .2021

\section{Introduction}

Adrenal insufficiency is caused by a failure of the adrenal cortex to produce cortisol. The most common cause of adrenal insufficiency is autosomal recessive inherited congenital adrenal hyperplasia (CAH, OMIM 201910) characterized by excess 
adrenal androgen production resulting from impairment of adrenal 21-hydroxylase $(21 \mathrm{OH})$ enzyme. Androgen excess affects approximately $10 \%$ of women (1). Disorders that resulted in the development of hyperandrogenism include polycystic ovary syndrome (PCOS, OMIM 184700) and 21OH deficient non-classic adrenal hyperplasia (21OHD-NCAH, OMIM 201910). PCOS aetiology is not known but it is a familial disorder that appears to be inherited as a complex genetic trait with a risk to siblings of $\sim 50 \%$. There is no accepted precise mode of inheritance $(2,3,4)$ and it is the most common endocrine disorder that affects $6 \%$ to $10 \%$ of reproductive-age women(5). Overall, it is difficult to clinically distinguish PCOS from NCAH (6). Of hyperandrogenic women, $1-10 \%$ is reported to be affected by NCAH due to $21 \mathrm{OHD}$ and NCAH can be even asymptomatic (7). In childhood, hyperandrogenism may present with premature pubarche (PP) and 5 to $20 \%$ of the PP cases were diagnosed with NCAH mainly due to 21OHD-NCAH $(8,9,10,11,12)$.

Standard dose synacthene stimulation test (SDSST) is the gold standard screening test to evaluate adrenal gland functions (13). It is the principal challenge test to estimate the relative activity of adrenocortical enzymes (14) and it has been widely used for the biochemical diagnosis of NCAH due to various adrenocortical enzyme deficiencies including 21OHD. A consensus is not available about whether heterozygous individuals with the CYP21A2 mutations have a higher risk of developing clinical hyperandrogenism. In some selected populations, being heterozygous for CYP21A2 seems to be related to irregular menses, hirsutism, PCOS, premature adrenarche (PA), acne, and central precocious puberty $(\mathrm{CPP})(12,15,16,17,18,19,20,21)$. In contrast, other investigators concluded that heterozygosity for CYP21 mutations did not increase the risk of clinical androgen excess above that expected in the general population $(22,23)$. The prevalence of asymptomatic carriers for the disease in the general population was estimated from 1:50 to as high as 1:16 (24) and even higher among Ashkenazi Jews, according to a single report (8). The frequencies of the mutation carrier of CYP21A2 were almost 1 in 4 in PP and hirsute groups $(21,25)$

The objectives of this meta-analysis is to determine the differences of the 17-OHP response to standard dose $(0.25 \mathrm{mg})$ synacthene stimulation in the diagnosis of CYP21A2 heterozygous individuals with or without clinical androgen excess and also to give an idea about the usability of the test and the cut-off levels to be applied.

\section{Materials and Methods}

\section{Search Strategy}

PubMed and MEDLINE databases were searched for the literature. The search strategy was kept broad, included several synonymous expressions, and performed using the keywords "21-hydroxylase" OR "CYP21A2" OR "21 $\alpha$-hydroxylase" OR "CYP21") AND "heterozygous" AND ("hirsutism” OR "hyperandrogenemia" OR "polycystic ovary syndrome" OR "PCOS" OR "acne" OR "alopecia" OR "oligomenorrhea" OR "adrenal hyperplasia" OR "adrenocorticotropic hormone (ACTH)". Only peerreviewed original articles were included in the study. Additional publications from the references of the included studies were manually searched by the investigators to identify the articles that may be missed by the electronic search.

\section{Study selection}

Human studies published between January 1995 and May 2020 were considered further. Studies without control groups were excluded, as well as those were written in the other languages rather than English. Since genetic mutation screening performed before 1995 was based on human leukocyte antigen (HLA) typing in most cases, studies performed before this date were excluded from the search criteria.

In the publications included in the study, mutation analyses were made using methods including amplification-refractory mutation system (ARMS), allele-specific oligonucleotide hybridization (ASOH), Sanger sequencing, single-strand conformation polymorphism (SSCP), multiplex ligation-de pendent probe amplification (MLPA), Southern Blot, sequence-specific oligonucleotide probes (SSOP), real-time quantitative reverse transcription-polymerase chain reaction (RT-qPCR) and multiplex mini-sequencing, and 17-OHP measurement was done using radioimmunoassay (RIA), enzyme-linked immunosorbent assay (ELISA), and liquid chromatography with tandem mass spectrometry (LC-MS/MS) methods.

The selection criteria were; 1) case-control studies 2) studies that evaluated the relationship between basal and/or stimulated 17OHP levels after SDSST in CYP21A2 carriers and non-carriers with one of the clinical hyperandrogenic symptoms including hirsutism, and/or oligo/amenorrhea and/or acne and/or elevation of at least one serum androgen 3) useable data on 17OHP levels to identify $21 \mathrm{OH}$ deficiency in patients with premature pubarche, premature adrenarche and premature thelarche (PT) 4) studies focused on differential diagnosis between NCAH and PCOS. The exclusion criteria were 1) case or family reports 2) studies that evaluated genetically confirmed $\mathrm{CAH}$ and NCAH patients 3) studies focused on diagnosis, treatment, review, method and general information 4) studies related to other diseases including Cushing syndrome, acromegaly, adrenal tumor, 11-hydroxylase $(11 \mathrm{OH})$, cytochrome $\mathrm{P} 450$ oxidoreductase $(P O R)$, 3-beta ( $\beta$ )-hydroxysteroid dehydrogenase (HSD3B2), and 17 $\alpha$ hydroxylase/17,20-lyase (CYP17A1) deficiencies (Figure 1).

\section{Data extraction and analysis}

Two authors independently screened the title, abstract and full text of potentially eligible studies twice at two different time points. Any disagreements were resolved by discussion or by seeking an independent third opinion. The titles and abstracts of the articles were examined and irrelevant ones were excluded. The full texts of the remaining articles were reviewed to find relevant studies that met the inclusion criteria. The Preferred Reporting Items for Systematic Reviews and Meta-Analyses (PRISMA) improves systematic reviews and were formed the basis for the selection protocol used in the current study (Figure 1). For all meta-analyses, Review Manager (RevMan) (2014) Version, 5.3 was used. A random-effects model and fixed-effect model were used while performing the meta-analyses. Due to the large degree of heterogeneity, random-effects model was applied. As known, the random-effects model does not adjust heterogeneity but it is a more conservative approach when the heterogeneity exists. Summary statistics were reported as standardized mean difference (SMD) and mean difference (MD) with $95 \%$ confidence intervals (CI). Standardized mean difference levels of $<0.2,>0.2$ and $<0.7$, or $>0.8$ were considered small and moderate, or large effects, respectively(26). Study-level mean (standard deviation; SD) and median (minimum-maximum) levels 
were reported. Study-level mean levels were used to generate receiver operating characteristic (ROC) curve by using SPSS 22 (Armonk, NY: IBM Corp)(27). While cut-off values were determined Youden's index was used and diagnostic accuracy measures were reported.

To form the standard units of measurement $(\mathrm{nmol} / \mathrm{L})$ in all the included articles, the 17-OHP was multiplied by 0.0303 and 3.0261 to convert $\mathrm{ng} / \mathrm{dL}$ to $\mathrm{nmol} / \mathrm{L}$ and $\mathrm{ng} / \mathrm{ml}$ to $\mathrm{nmol} / \mathrm{L}$, respectively.

Patients

Individuals from both gender "female and male" with CYP21A2 heterozygous mutation carriers and non-carriers between 0.7-65 years of age were included in the study (Table 1). The study groups consisted of females and/or males with PCOS, PP, PA, PT and clinical hyperandrogenism, relatives of patients with $\mathrm{CAH}$ or $\mathrm{NCAH}$, and healthy controls. Mutation analysis of the CYP21A2 gene and SDSST were applied to all volunteers participating in the study.

\section{Heterogeneity and Publication Bias}

Between-study variability was compared with within-study variability (i.e., heterogeneity of effect size) using the $\mathrm{I}^{2}$ statistic which measures the percentage of variation due to heterogeneity (28). An $\mathrm{I}^{2}$ level less than $25 \%$ indicated low heterogeneity, whereas levels between 35 to 50\% showed moderate heterogeneity and those above 50\% showed high heterogeneity $(28)$. Publication bias was assessed using contour-enhanced funnel plots (29).

\section{Results}

\section{Search Results}

Three hundred sixty-five relevant publications were searched after the screening of studies published between 1995 and 2020 . After excluding repetitive and irrelevant publications, fifteen high-quality peer-reviewed publications that met inclusion criteria were included in the meta-analyses. These studies were carried out in Europe, the United States of America (USA), and Russia. Three studies were carried out in Greece $(15,30,31)$, three in USA(18,32,33), two in Italy $(34,35)$, two in Brazil $(36,37)$, two in France(38,39), one in Turkey(21), one in Russia(40) and one in Israel(41). CYP21A2 mutation analysis and basal and/or stimulated 17OHP measurements were applied to all volunteers who participated in the study. The SDSST was performed in patients by administration of a single intravenous dose of $0.25 \mathrm{mg}$ synacthene (synthetic ACTH). Measurements of the basal and stimulated serum 17OHP levels were done after 30 or 60 minutes of synacthene administration.

Among the included studies, two of them were added to the relevant sub-analysis since they only included basal 17-OHP measurements $(31,40)$. Two different control groups were determined in the included studies; a mutation-free asymptomatic healthy volunteer group (asymptomatic heterozygous vs. asymptomatic mutation-free healthy control), and a mutation-free but clinically symptomatic volunteer group (symptomatic heterozygous vs. symptomatic mutation-free control) therefore, these two were analysed in two separate analyses to make clear discrimination. In a study, since 17-OHP levels were given separately based on two different clinical findings, the same study was included twice with different data sets (18). Whereas 17-OHP level measured in a publication was remarkably high in both groups compared to given 17-OHP levels in other publications used in the meta-analyses, the study was included in the analysis since it met the inclusion criteria (36). One thousand and two hundred fifteen subjects (21OH-heterozygous carriers n: 669, mutation-free controls n: 546) were included in the meta-analyses (Table 1).

Comparison of Basal and Stimulated 17-OHP Levels Symptomatic Heterozygous vs. Symptomatic Mutation-Free Control

The fixed-effects model was used in the meta-analysis using basal 17-OHP levels because the heterogeneity of the studies was low $\left(\mathrm{I}^{2}=0 \%, \mathrm{p}=0.620\right)$. In the symptomatic heterozygous carriers, the level of the mean difference was found to be higher than symptomatic mutation-free controls (MD: $0.70 \mathrm{nmol} / \mathrm{L}, 95 \% \mathrm{CI}: 0.21-1.18, \mathrm{Z}=2.81, \mathrm{p}=0.005$ ). When the mean difference was standardized, the difference was determined to have a medium effect size (SMD: $0.33 \mathrm{nmol} / \mathrm{L}, 95 \% \mathrm{CI}: 0.14-0.51, \mathrm{Z}=3.42$, $\mathrm{p}<0.001$ ) (Figure 2).

When comparing the stimulated levels of 17-OHP in symptomatic heterozygous carriers and symptomatic mutation-free controls, the random-effects model was used due to significant heterogeneity $\left(\mathrm{I}^{2}=72 \%, \mathrm{p}<0.001\right)$ of the study. The mean differences were found to be higher in the heterozygous carriers (MD: $7.20 \mathrm{nmol} / \mathrm{L}, 95 \% \mathrm{CI}: 5.15-9.25, \mathrm{Z}=6.87, \mathrm{p}<0.001$ ). The standardized mean difference (SMD: $0.9 \mathrm{nmol} / \mathrm{L}, 95 \% \mathrm{CI}: 0.46-1.34, \mathrm{Z}=4.01, \mathrm{p}<0.001)$ shows that the difference has a large effect size (Figure 2).

The ROC curve for symptomatic heterozygous and symptomatic mutation-free control were shown in figure 3A\&B, demonstrating that stimulated 17-OHP provides good discrimination $(\mathrm{AUC}=0.80, \mathrm{p}=0.034)$ between symptomatic heterozygous and symptomatic mutation-free control with an optimal cut-off of $13.41 \mathrm{nmol} / \mathrm{L}$, yielding a sensitivity of $100 \%$ and a specificity of $66.7 \%$. Basal 17-OHP level was not found informative to discriminate heterozygous and wild type in the symptomatic group (Table 2).

\section{Asymptomatic Heterozygous vs. Asymptomatic Mutation-Free Healthy Control}

The fixed-effects model was used in the analysis of basal 17-OHP levels in asymptomatic heterozygous carriers with the asymptomatic mutation-free healthy controls due to the low heterogeneity of the studies $\left(\mathrm{I}^{2}=0 \%, \mathrm{p}=0.53\right)$. Basal $17-\mathrm{OHP}$ level was higher in asymptomatic heterozygous carriers than in asymptomatic mutation-free healthy controls (MD: $0.62 \mathrm{nmol} / \mathrm{L}, 95 \%$ CI: $0.20-1.04, \mathrm{Z}=2.92, \mathrm{p}<0.001$ ). The standardized mean difference in the groups was $0.27 \mathrm{nmol} / \mathrm{L}$ (SMD: $0.27,95 \% \mathrm{CI}: 0.10$ $0.45, Z=3.04, p=0.002$ ), and this difference was determined to have a medium effect size (Figure 4).

When comparing the stimulated level of 17-OHP in asymptomatic heterozygous carriers and asymptomatic mutation-free healthy controls, the random-effects model was used due to significant heterogeneity $\left(\mathrm{I}^{2}=85 \%, \mathrm{p}<0.001\right)$. 17-OHP level was higher in asymptomatic heterozygous carriers than in asymptomatic mutation-free healthy controls (MD: $7.57 \mathrm{nmol} / \mathrm{L}, 95 \% \mathrm{CI}: 6.82-8.32$ ). The standardized mean difference in the groups was $1.34 \mathrm{nmol} / \mathrm{L}$ (SMD: 1.34, 95\% CI: $0.81-1.87, \mathrm{Z}=4.99, \mathrm{p}<0.001$ ), and the 
effect size for this difference was similar to the symptomatic heterozygous vs. symptomatic mutation-free controls comparison (Figure 4).

The ROC curve for asymptomatic heterozygous and asymptomatic mutation-free healthy control were shown in figure 3C\&D, demonstrating that stimulated 17-OHP provides good discrimination (AUC $=1.0, \mathrm{p}=0.009$ ) between symptomatic heterozygous and symptomatic mutation-free healthy control with an optimal cut-off of $10.48 \mathrm{nmol} / \mathrm{L}$, yielding a sensitivity of $100 \%$ and a specificity of $100 \%$. Basal 17-OHP level was not found informative to discriminate heterozygous and wild type in the asymptomatic group (Table 2).

\section{Median and Mean of Basal and Stimulated 17-OHP Levels}

Study-level median and mean were calculated after elimination of the publication with extreme basal and stimulated 17-OH levels (36). Basal 17-OHP median levels were detected to be 4.156(3.05-10.5) nmol/L and 3.90(2.20-9.74) nmol/L in symptomatic heterozygous carriers and symptomatic mutation-free controls, respectively. Basal 17-OHP mean levels were detected to be $5.24( \pm 2.59) \mathrm{nmol} / \mathrm{L}$ and $4.67( \pm 2.62) \mathrm{nmol} / \mathrm{L}$ in symptomatic heterozygous carriers and symptomatic mutation-free controls, respectively. Stimulated 17-OHP median levels were determined to be 17.29(14.22-37.2) nmol/L and 9.27(7.32-15.9) $\mathrm{nmol} / \mathrm{L}$ in symptomatic heterozygous carriers and symptomatic mutation-free controls, respectively. Stimulated 17-OHP mean levels were determined to be $19.51( \pm 7.63) \mathrm{nmol} / \mathrm{L}$ and $10.77( \pm 3.48) \mathrm{nmol} / \mathrm{L}$ in symptomatic heterozygous carriers and symptomatic mutation-free controls, respectively. Basal 17-OHP median levels were determined to be 3.21(2.64- 4.78) nmol/L and $3.12(1.82-3.6) \mathrm{nmol} / \mathrm{L}$ in asymptomatic heterozygous carriers and asymptomatic mutation-free healthy controls, respectively. Basal 17-OHP mean levels were determined to be 3.33( \pm 0.84$) \mathrm{nmol} / \mathrm{L}$ and $2.84( \pm 0.71) \mathrm{nmol} / \mathrm{L}$ in asymptomatic heterozygous carriers and asymptomatic mutation-free healthy controls, respectively. Stimulated 17-OHP median levels were found to be 14.16(12.73-16.37) nmol/L and 6.26(4.9-8.23) nmol/L in asymptomatic heterozygous carriers and asymptomatic mutation-free healthy controls, respectively (Figure 5). Stimulated 17-OHP mean levels were found to be $14.16( \pm 1.37) \mathrm{nmol} / \mathrm{L}$ and $6.48( \pm 1.2)$ $\mathrm{nmol} / \mathrm{L}$ in asymptomatic heterozygous carriers and asymptomatic mutation-free healthy controls, respectively.

\section{Heterogeneity and Publication Bias}

Funnel plots were drawn in both fixed and random-effect models to determine whether there was a publication bias in the included papers. In both models, confidence intervals were also presented in the funnel plot. As funnel plots seemed almost symmetrical in all meta-analyses, we concluded that publication bias was weak (Figure 6).

\section{Discussion}

Measurement of serum 17-OHP was introduced in 1968 (42), and it is now used most widely for the diagnosis of adrenal enzymatic defects (43) in combination with SDSST which is a gold standard and commonly used biochemical test in the evaluation of adrenal gland functions. The SDSST in the evaluation of the adrenal gland functions has been investigated in various clinical conditions, such as pre-clinical Addison's disease (44) right away immediately after pituitary surgery (45), patients with primary hypothyroidism (46), and in patients with primary fibromyalgia syndrome(47), in women with PCOS (48) and hirsutism and/or oligomenorrhea (49), in adolescents with PP (15), in patients with CAH or NCAH (50). Compared to normal female individuals, female carriers for $21-\mathrm{OHD}$ frequently demonstrate an exaggerated secretion of the $21-\mathrm{OH}$ precursors 17-OHP after ACTH administration(51). In fact, $50 \%$ and $80 \%$ of carriers exhibit $17-$ OHP level above the $95^{\text {th }}$ percentile of the control level after ACTH stimulation (51,52,53).

To our knowledge, this is the first meta-analysis on differences of 17-OHP response to SDSST in heterozygous and mutation-free symptomatic and asymptomatic volunteers considering only high-quality studies with the same SDSST criteria and CYP21A2 mutation analyses on molecular level except HLA typing. In the literature, SDSST was recommended when the basal 17-OHP $\geq$ $6 \mathrm{nmol} / \mathrm{L}$ so, $210 H D-N C A H$ was unlikely in the case with lower basal 17-OHP in widely accepted opinion. Possible heterozygote carrier status was considered for the patients with baseline $17-\mathrm{OHP}>6 \mathrm{nmol} / \mathrm{L}$ or those with baseline $17-\mathrm{OHP}<6$ $\mathrm{nmol} / \mathrm{L}$ and ACTH stimulated $17-\mathrm{OHP}<30 \mathrm{nmol} / \mathrm{L}(54,55)$. Stimulated $17 \mathrm{OHP}>30 \mathrm{nmol} / \mathrm{L}$ was considered as the criterion for $21 \mathrm{OH}$ deficiency-related NCAH (56). In another study, patients were considered to be heterozygote carriers of $21 \mathrm{OHD}$ with ACTH- stimulated 17-OHP concentrations between $12.1-30.2 \mathrm{nmol} / \mathrm{L}(57)$. In another study, stimulated 17-OHP levels above 45 $\mathrm{nmol} / \mathrm{L}$ after ACTH stimulation were suggested as NCAH; the levels between 15 and 45 nmol/L were suggested as a mutation carrier, and levels below $15 \mathrm{nmol} / \mathrm{L}$ were interpreted as normal(41).

In our study, MD and SMD of the basal 17-OHP were determined as $0.7 \mathrm{nmol} / \mathrm{L}$ and $0.33 \mathrm{nmol} / \mathrm{L}$ in the symptomatic group while MD and SMD in the asymptomatic group were $0.62 \mathrm{nmol} / \mathrm{L}$ and $0.27 \mathrm{nmol} / \mathrm{L}$ compared to the control group, respectively. SMD levels in both groups were determined to be slightly higher than the small effect size limit of $<0.2$. When the median levels of both groups were calculated, basal 17-OHP median levels were determined to be $4.156 \mathrm{nmol} / \mathrm{L}(3.05-10.5)$ and $3.765 \mathrm{nmol} / \mathrm{L}$ (2.20-9.74) in the symptomatic heterozygous carriers and symptomatic mutation-free controls, respectively. In the asymptomatic groups, basal 17-OHP median levels were determined as $3.21 \mathrm{nmol} / \mathrm{L}$ (2.64-4.78) and 3.12 nmol/L (1.82-3.6) in the heterozygous carriers and mutation-free healthy controls, respectively. In our meta-analyses, in the asymptomatic group, both the basal median 17-OHP level and the SMD level were found to be lower than in the symptomatic group. The researchers try to identify a cut-off level for basal 17-OHP that will exclude the diagnosis of NCAH and avoid unnecessary SDSST especially for countries where synthetic ACTH is not widely available (58). Temeck et al. found that $13-14 \%$ of patients with NCAH would be missed if the basal 17-OHP level of $6 \mathrm{nmol} / \mathrm{L}$ was used (59). Escobar-Morreale et al. proposed a cut-off level of $5.1 \mathrm{nmol} / \mathrm{L}$ with $100 \%$ sensitivity and $88.6 \%$ specificity in the cohort of women with hyperandrogenism (60). Leite et al. showed that basal level of $17-$ $\mathrm{OHP}>3 \mathrm{nmol} / \mathrm{L}$ was sufficient for the diagnosis of NCAH(11). Gonc et al. determined that only one of the NCAH cases would be missed when $4.69 \mathrm{nmol} / \mathrm{L}$ was used as the basal 17-OHP cut-off level in patients with PA, the authors also suggested that including the patient's clinical phenotype to evaluation of the basal 17-OHP level can increase the accuracy of the SDSST (61). On the other hand, there is no consensus in the determination of heterozygosity, therefore 17-OHP level between NCAH and 
normal is accepted as heterozygous(41).

In these meta-analyses, MD and SMD of the stimulated $17-\mathrm{OHP}$ were $7.2 \mathrm{nmol} / \mathrm{L}$ and $0.9 \mathrm{nmol} / \mathrm{L}$ in the symptomatic group, and $7.57 \mathrm{nmol} / \mathrm{L}$ and $1.34 \mathrm{nmol} / \mathrm{L}$ in the asymptomatic group, respectively. SMD levels in both groups were higher than the large effect size limit of $>0.8$. The stimulated 17-OHP median levels were determined to be $17.29 \mathrm{nmol} / \mathrm{L}(14.22-37.2)$ and 9.27 $\mathrm{nmol} / \mathrm{L}$ (7.32-15.9) in symptomatic heterozygous carriers and symptomatic mutation-free controls, respectively, additionally, stimulated 17-OHP median levels were determined as $14.16 \mathrm{nmol} / \mathrm{L}(12.73-16.37)$ and $6.26 \mathrm{nmol} / \mathrm{L}$ (4.9-8.23) in asymptomatic heterozygous carriers and asymptomatic mutation-free healthy controls, respectively. The ROC analysis showed that the basal 17-OHP level was not discriminative in both symptomatic and asymptomatic groups, but the stimulated 17-OHP level was found informative. The cut-off level for the asymptomatic heterozygous individuals was $10.48 \mathrm{nmol} / \mathrm{L}$, while the cut-off level for the symptomatic group was $13.41 \mathrm{nmol} / \mathrm{L}$. Both the cut-off levels were lower than $15 \mathrm{nmol} / \mathrm{L}$, which were interpreted as normal. Besides, the stimulated 17-OHP median level of symptomatic mutation-free controls was higher than that of asymptomatic mutation-free healthy controls ( $9.27 \mathrm{vs.} 6.26 \mathrm{nmol} / \mathrm{L})$. Similarly, the stimulated 17-OHP median level of symptomatic heterozygous carriers was higher than that of asymptomatic heterozygous carriers $(17.29 \mathrm{vs} 14.16 \mathrm{nmol} / \mathrm{L})$. The stimulated OHP level of the symptomatic group was determined in the heterozygous range $(>15 \mathrm{nmol} / \mathrm{L}$ and $<45 \mathrm{nmol} / \mathrm{L})$, while it was below the level considered heterozygous $(<15 \mathrm{nmol} / \mathrm{L})$ in the asymptomatic group. The result may support the idea that clinical phenotype effects the test. Similarly, Admoni et al. made a comparison between symptomatic heterozygous and family member carriers, which revealed that the symptomatic carriers had a significantly higher ACTH-stimulated 17-OHP than family member carriers(41).

CYP21A2 gene mutation is not the only factor causing androgen excess symptoms, other hormones or genes may also play a role in the similar clinical phenotype. Additionally, both adrenal and gonadal steroid hormone biosynthesis is a complex phenomenon, regulated by the feedback mechanism between different tissues and dozens of genes belonging to different gene families. The biosynthesis pathways have not been elucidated yet and retains many unknowns $(62)$

The heterozygous mutation carrier of the CYP21A2 gene has to be considered in the differential diagnosis of hyperandrogenic symptoms (63). Determination of the mutation carrier is also compulsory for genetic counselling of the parents affected by $\mathrm{CAH} / \mathrm{NCAH}$ and in families which includes a parent with confirmed heterozygous mutation since the genetic counselling plays an important role in the control of genetic diseases. The heterozygous individuals may be diagnosed with NCAH due to falsepositivity of the SDSST, especially in V281L heterozygous mutation (21). Therefore, there is a need for up-to-date studies on the specificity and sensitivity of the SDSST to distinguish CYP21A2 carriers and 21OHD-NCAH.

The V281L mutation is compatible with the NCAH allele and the protein with the leucine amino acid exhibits $30-50 \%$ remaining enzymatic activity(64), it was determined that the ACTH test result gave a level close to the cut-off level used for NCAH in the heterozygous V281L mutation $(21,41)$. Escobar- Morreale et al. hypothesized one possible explanation for the abnormal 21hydroxylase function in subjects with one normal allele and a "half functioning" allele was a dominant-negative mutation; a mutation its gene product adversely affects the wild-type gene product within the same cell(23) as seen in different diseases like familial hypertrophic cardiomyopathy(65) and alfa-mannosidosis (66).

Considering the developing technology, more precise basal and stimulated 17-OHP cut-off levels can be determined by combining the recently common and inexpensive genetic analysis results with the more precise hormone measurements performed by the use of LC/MS-MS. This kind of work can be valuable under conditions in which hormone determinations are possible but access to genetic testing is limited due to financial restrictions of health care systems or health insurances. Moreover, the SDSST is faster and cheaper than genetic analyses. Besides, we suggest that adding the clinical phenotype and the type of mutation to basal and stimulated $17-\mathrm{OHP}$ evaluation may increase the accuracy of the test and yield better results. Our study had few limitations, firstly, included articles did not report data separately by gender, secondly, the volunteers in the publications were in a wide age range, thirdly, copy number variation of CYP21A2 was not investigated in all studies included in the analyses, thirdly, study assays, number of individuals and 17- OHP units differ between included studies. Our study has also strengths; firstly, a genetic analysis was performed in all the volunteers. Secondly, almost all 17-OHP measurements were done by using the same hormone measurements method (RIA), except two studies $(37,40)$. In conclusion, the meta-analyses support the idea that the stimulated 17-OHP level has the potential to use for the determination of the CYP21A2 carriers by SDSST, although basai 17-OHP level may not be informative. The ROC curve analysis from study-level data could produce some bias, therefore the cut-off values from our study should be used with caution, additionally the SDSST needs further investigation to increase specificity and sensitivity to determine heterozygosity. A higher increment of the stimulated 17-OHP level in mutationfree symptomatic individuals than those who were asymptomatic was found in the meta-analyses. Therefore, individuals might be evaluated better by the SDSST considering the clinical phenotype and type of mutation to increase the accuracy of the test. Funding

This research did not receive any specific grant from funding agencies in the public, commercial, or not-for-profit sectors. Conflict of interest

The authors declare that there is no conflict of interest relevant to the subject matter or materials included in this work.

Acknowledge

Thanks to Dr. Yasin Şimşek, an endocrinologist, for his contribution to the meta-analyses as a third opinion.

References 
1. Azziz R, Sanchez LA, Knochenhauer ES, Moran C, Lazenby J, Stephens KC, Taylor K, Boots LR. Androgen excess in women: experience with over 1000 consecutive patients. The Journal of clinical endocrinology and metabolism 2004;89:453-462. Epub 2004/02/07

2. Barber TM, Franks S. Genetics of Polycystic Ovary Syndrome. Polycystic Ovary Syndrome: Novel Insight into Causes and Therapy 2013;40:28-39.

3. Panda PK, Rane R, Ravichandran R, Singh S, Panchal H. Genetics of PCOS: A systematic bioinformatics approach to unveil the proteins responsible for PCOS. Genom Data 2016;8:52-60.

4. Gharani N, Waterworth DM, Batty S, White D, Gilling-Smith C, Conway GS, McCarthy M, Franks S, Williamson R Association of the steroid synthesis gene CYP11a with polycystic ovary syndrome and hyperandrogenism. Hum Mol Genet 1997;6:397-402.

5. Kahsar-Miller MD, Nixon C, Boots LR, Go RC, Azziz R. Prevalence of polycystic ovary syndrome (PCOS) in firs degree relatives of patients with PCOS. Fertility and sterility 2001;75:53-58. Epub 2001/02/13

6. Robyr D, Llor J, Gaudin G, Schneider N. [Polycystic ovary syndrome and congenital adrenal hyperplasia: a different entity for comparable phenotypes?]. Revue medicale suisse 2007;3:1595-1596, 1598, 1600-1591. Epub 2007/08/3

7. Nandagopal R, Sinaii N, Avila NA, Van Ryzin C, Chen W, Finkielstain GP, Mehta SP, McDonnell NB, Merke D Phenotypic profiling of parents with cryptic nonclassic congenital adrenal hyperplasia: findings in 145 unrelated families. European journal of endocrinology / European Federation of Endocrine Societies 2011;164:977-984. Epub 2011/03/30

8. New MI. Extensive clinical experience: nonclassical 21-hydroxylase deficiency. The Journal of clinical endocrinology and metabolism 2006;91:4205-4214. Epub 2006/08/17

9. Siegel SF, Finegold DN, Urban MD, McVie R, Lee PA. Premature pubarche: etiological heterogeneity. J Clin Endocrinol Metab 1992;74:239-247.

10. Delbalzo P, Borrelli P, Cambiaso P, Danielli E, Cappa M. Adrenal Steroidogenic Defects in Children with Precocious Pubarche. Horm Res 1992;37:180-184.

11. Leite MV, Mendonca BB, Arnhold IJ, Estefan V, Nunes C, Nicolau W, Bloise W. Identification of nonclassical 21hydroxylase deficiency in girls with precocious pubarche. J Endocrinol Invest 1991;14:11-

12. Azziz R, Owerbach D. Molecular abnormalities of the 21-hydroxylase gene in hyperandrogenic women with an exaggerated 17-hydroxyprogesterone response to short-term adrenal stimulation. Am J Obstet Gynecol 1995;172:914-918.

13. Hasinski S. Assessment of adrenal glucocorticoid function. Which tests are appropriate for screening? Postgrad Med 1998;104:61-64, 69-72.

14. Azziz R, Rafi A, Smith BR, Bradley EL, Jr., Zacur HA. On the origin of the elevated 17-hydroxyprogesterone levels after adrenal stimulation in hyperandrogenism. The Journal of clinical endocrinology and metabolism 1990;70:431-436. Epub 1990/02/01

15. Dacou-Voutetakis C, Dracopoulou M. High incidence of molecular defects of the CYP21 gene in patients with premature adrenarche. J Clin Endocrinol Metab 1999;84:1570-1574

16. Witchel SF, Aston CE. The role of heterozygosity for CYP21 in the polycystic ovary syndrome. J Pediatr Endocrinol Metab 2000;13 Suppl 5:1315-1317.

17. Blanche H, Vexiau P, Clauin S, Le Gall I, Fiet J, Mornet E, Dausset J, Bellanne-Chantelot C. Exhaustive screening of the 21-hydroxylase gene in a population of hyperandrogenic women. Hum Genet 1997;101:56-60.

18. Witchel SF, Lee PA, Suda-Hartman M, Hoffman EP. Hyperandrogenism and manifesting heterozygotes for 21hydroxylase deficiency. Biochem Mol Med 1997;62:151-158.

19. Cisternino M, Dondi E, Martinetti M, Lorini R, Salvaneschi L, Cuccia M, Severi F. Exaggerated 17-

hydroxyprogesterone response to short-term adrenal stimulation and evidence for CYP21B gene point mutations in true precocious puberty. Clin Endocrinol (Oxf) 1998;48:555-560.

20. Ostlere LS, Rumsby G, Holownia P, Jacobs HS, Rustin MHA, Honour JW. Carrier status for steroid 21-hydroxylase deficiency is only one factor in the variable phenotype of acne. Clin Endocrinol 1998;48:209-215.

21. Polat S, Karaburgu S, Unluhizarci K, Dundar M, Ozkul Y, Arslan YK, Karaca Z, Kelestimur F. Comprehensive genotyping of Turkish women with hirsutism. J Endocrinol Invest 2019;42:1077-1087.

22. Knochenhauer ES, Cortet-Rudelli C, Cunnigham RD, Conway-Myers BA, Dewailly D, Azziz R. Carriers of 21hydroxylase deficiency are not at increased risk for hyperandrogenism. J Clin Endocrinol Metab 1997;82:479-485.

23. Escobar-Morreale HF, San Millan JL, Smith RR, Sancho J, Witchel SF. The presence of the 21-hydroxylase deficiency carrier status in hirsute women: phenotype-genotype correlations. Fertil Steril 1999;72:629-638.

24. Moran C, Azziz R, Weintrob N, Witchel SF, Rohmer V, Dewailly D, Marcondes JA, Pugeat M, Speiser PW, Pignatelli D, Mendonca BB, Bachega TA, Escobar-Morreale HF, Carmina E, Fruzzetti F, Kelestimur F. Reproductive outcome of women with 21-hydroxylase-deficient nonclassic adrenal hyperplasia. J Clin Endocrinol Metab 2006;91:3451-3456.

25. Potau N, Rique S, Eduardo I, Marcos V, Ibanez L. Molecular defects of the CYP21 gene in Spanish girls with isolated precocious pubarche. Eur J Endocrinol 2002;147:485-488.

26. Cohen J. Statistical Power Analysis for the Behavioral Sciences. 1988;2nd ed.

27. Hariyanto TI, Japar KV, Kwenandar F, Damay V, Siregar JI, Lugito NPH, Tjiang MM, Kurniawan A. Inflammatory and hematologic markers as predictors of severe outcomes in COVID-19 infection: A systematic review and meta-analysis. Am J Emerg Med 2021;41:110-119.

28. Higgins JPT, Thompson SG, Deeks JJ, Altman DG. Measuring inconsistency in meta-analyses. Brit Med J 2003;327:557-560. 

Phylactou LA, Skordis N. Variations in the 3'UTR of the CYP21A2 Gene in Heterozygous Females with Hyperandrogenaemia. Int J Endocrinol 2017;2017:8984365.

31. Settas N, Dracopoulou-Vabouli M, Dastamani A, Katsikis I, Chrousos G, Panidis D, Dacou-Voutetakis C. CYP21A2 mutations in women with polycystic ovary syndrome (PCOS). Horm Metab Res 2013;45:383-386.

32. Witchel SF, Lee PA, Suda-Hartman M, Trucco M, Hoffman EP. Evidence for a heterozygote advantage in congenital adrenal hyperplasia due to 21-hydroxylase deficiency. J Clin Endocrinol Metab 1997;82:2097-2101.

33. Witchel SF, Lee PA. Identification of heterozygotic carriers of 21-hydroxylase deficiency: sensitivity of ACTH stimulation tests. Am J Med Genet 1998;76:337-342.

34. Oriolo C, Fanelli F, Castelli S, Mezzullo M, Altieri P, Corzani F, Pelusi C, Repaci A, Di Dalmazi G, Vicennati V, Baldazzi L, Menabo S, Dormi A, Nardi E, Brillanti G, Pasquali R, Pagotto U, Gambineri A. Steroid biomarkers for identifying non-classic adrenal hyperplasia due to 21-hydroxylase deficiency in a population of PCOS with suspicious levels of 17OHprogesterone. J Endocrinol Invest 2020 doi: 10.1007/s40618-020-01235-3.

35. Napolitano E, Manieri C, Restivo F, Composto E, Lanfranco F, Repici M, Pasini B, Einaudi S, Menegati E.

Correlation between genotype and hormonal levels in heterozygous mutation carriers and non-carriers of 21-hydroxylase deficiency. J Endocrinol Invest 2011;34:498-501.

36. Bachega TA, Billerbeck AE, Marcondes JA, Madureira G, Arnhold IJ, Mendonca BB. Influence of different genotypes on 17-hydroxyprogesterone levels in patients with nonclassical congenital adrenal hyperplasia due to 21-hydroxylase deficiency. Clin Endocrinol (Oxf) 2000;52:601-607.

37. Costa-Barbosa FA, Tonetto-Fernandes VF, Carvalho VM, Nakamura OH, Moura V, Bachega TA, Vieira JG, Kater CE. Superior discriminating value of ACTH-stimulated serum 21-deoxycortisol in identifying heterozygote carriers for 21hydroxylase deficiency. Clin Endocrinol (Oxf) 2010;73:700-706.

38. Paris F, Tardy V, Chalancon A, Picot MC, Morel Y, Sultan C. Premature pubarche in Mediterranean girls: high prevalence of heterozygous CYP21 mutation carriers. Gynecol Endocrinol 2010;26:319-324.

39. Bidet M, Bellanne-Chantelot C, Galand-Portier MB, Tardy V, Billaud L, Laborde K, Coussieu C, Morel Y, Vaury C, Golmard JL, Claustre A, Mornet E, Chakhtoura Z, Mowszowicz I, Bachelot A, Touraine P, Kuttenn F. Clinical and molecular characterization of a cohort of 161 unrelated women with nonclassical congenital adrenal hyperplasia due to 21-hydroxylase deficiency and 330 family members. J Clin Endocrinol Metab 2009;94:1570-1578.

40. Grodnitskaya E, Kurtser M. The prevalence of non-classic congenital adrenal hyperplasia due to 21-hydroxylase deficiency in Russian women with hyperandrogenism. Hum Fertil (Camb) 2018,21:281-287.

41. Admoni O, Israel S, Lavi I, Gur M, Tenenbaum-Rakover Y. Hyperandrogenism in carriers of CYP21 mutations: the role of genotype. Clin Endocrinol (Oxf) 2006;64:645-651.

42. Strott CA, Lipsett MB. Measurement of 17-hydroxyprogesterone in human plasma. J Clin Endocrinol Metab 1968;28:1426-1430.

43. Barnes ND, Atherden SM. Diagnosis of congenital adrenal hyperplasia by measurement of plasma 17-

hydroxyprogesterone. Arch Dis Child 1972;47:62-65.

44. Laureti S, Arvat E, Candeloro P, Di Vito L, Ghigo E, Santeusanio F, Falorni A. Low dose (1 microg) ACTH test in the evaluation of adrenal dysfunction in pre-clinical Addison's disease. Clin Endocrinol (Oxf) 2000;53:107-115.

45. Dokmetas HS, Colak R, Kelestimur F, Selcuklu A, Unluhizarci K, Bayram F. A comparison between the 1-microg adrenocorticotropin $(\mathrm{ACTH})$ test, the short ACTH $(250 \mathrm{microg})$ test, and the insulin tolerance test in the assessment of hypothalamo-pituitary-adrenal axis immediately after pituitary surgery. J Clin Endocrinol Metab 2000;85:3713-3719.

46. Unluhizarci K, Bayram F, Guven M, Kula M, Colak R, Kelestimur F. Cortisol responses to low (1 microg) and standard (250 microg) dose ACTH stimulation tests in patients with primary hypothyroidism. Clin Endocrinol (Oxf) 2001;54:700-702.

47. Kirnap M, Colak R, Eser C, Ozsoy O, Tutus A, Kelestimur F. A comparison between low-dose (1 microg), standarddose (250 microg) ACTH stimulation tests and insulin tolerance test in the evaluation of hypothalamo-pituitary-adrenal axis in primary fibromyalgia syndrome. Clin Endocrinol (Oxf) 2001;55:455-459.

48. Colak R, Kelestimur F, Unluhizarci K, Bayram F, Sahin Y, Tutus A. A comparison between the effects of low dose (1 microg) and standard dose (250 microg) ACTH stimulation tests on adrenal P450c17alpha enzyme activity in women with polycystic ovary syndrome. Eur J Endocrinol 2002;147:473-477.

49. Turner EI, Watson MJ, Perry LA, White MC. Investigation of adrenal function in women with oligomenorrhoea and hirsutism (clinical PCOS) from the north-east of England using an adrenal stimulation test. Clin Endocrinol (Oxf) 1992;36:389397.

50. Armengaud JB, Charkaluk ML, Trivin C, Tardy V, Breart G, Brauner R, Chalumeau M. Precocious pubarche: distinguishing late-onset congenital adrenal hyperplasia from premature adrenarche. The Journal of clinical endocrinology and metabolism 2009;94:2835-2840. Epub 2009/05/21

Peter M, Sippell WG, Lorenzen F, Willig RP, Westphal E, Grosse-Wilde H. Improved test to identify heterozygotes for congenital adrenal hyperplasia without index case examination. Lancet 1990;335:1296-1299.

52. Gutai JP, Kowarski AA, Migeon CJ. The detection of the heterozygous carrier for congenital virilizing adrenal hyperplasia. J Pediatr 1977;90:924-929. 
53. Handelsman DJ, Howe CJ, Conway AJ, Turtle JR. Heterozygote detection in congenital adrenal hyperplasia. Clin Chem 1983;29:48-50.

54. Speiser PW, White PC. Congenital adrenal hyperplasia. The New England journal of medicine 2003;349:776-788. Epub 2003/08/22

55. Dracopoulou-Vabouli M, Maniati-Christidi M, Dacou-Voutetakis C. The spectrum of molecular defects of the CYP21 gene in the Hellenic population: variable concordance between genotype and phenotype in the different forms of congenital adrenal hyperplasia. J Clin Endocrinol Metab 2001;86:2845-2848.

56. New MI, Lorenzen F, Lerner AJ, Kohn B, Oberfield SE, Pollack MS, Dupont B, Stoner E, Levy DJ, Pang S, Levine LS. Genotyping steroid 21-hydroxylase deficiency: hormonal reference data. J Clin Endocrinol Metab 1983;57:320-326.

57. Fiet J, Villette JM, Galons H, Boudou P, Burthier JM, Hardy N, Soliman H, Julien R, Vexiau P, Gourmelen M, et al. The application of a new highly-sensitive radioimmunoassay for plasma 21-deoxycortisol to the detection of steroid-21hydroxylase deficiency. Ann Clin Biochem 1994;31 ( Pt 1):56-64.

58. Maffazioli GDN, Bachega T, Hayashida SAY, Gomes LG, Valassi HPL, Marcondes JAM, Mendonca BB, Baracat EC, Maciel GAR. Steroid Screening Tools Differentiating Nonclassical Congenital Adrenal Hyperplasia and Polycystic Ovary Syndrome. J Clin Endocrinol Metab 2020;105.

59. Temeck JW, Pang SY, Nelson C, New MI. Genetic defects of steroidogenesis in premature pubarche. J Clin Endocrinol Metab 1987;64:609-617.

60. Escobar-Morreale HF, Sanchon R, San Millan JL. A prospective study of the prevalence of nonclassical congenital adrenal hyperplasia among women presenting with hyperandrogenic symptoms and signs. J Clin Endocrinol Metab 2008;93:527533.

61. Gonc EN, Ozon ZA, Alikasifoglu A, Engiz O, Bulum B, Kandemir N. Is basal serum 17-OH progesterone a reliable parameter to predict nonclassical congenital adrenal hyperplasia in premature adrenarche? Turkish J Pediatr 2011;53:274-280.

62. Miller WL, Auchus RJ. The molecular biology, biochemistry, and physiology of human steroidogenesis and its disorders. Endocrine reviews 2011;32:81-151. Epub 2010/11/06

63. Kulle AE, Riepe FG, Hedderich J, Sippell WG, Schmitz J, Niermeyer L, Holterhus PM. LC-MS/MS based determination of basal- and ACTH-stimulated plasma concentrations of 11 steroid hormones: implications for detecting heterozygote CYP21A2 mutation carriers. Eur J Endocrinol 2015;173:517-524.

64. Barr M. A study of genetic variability at the CYP11B2/B1 locus and its importance in human hypertension. MRC Blood Pressure Group, Glasgow Cardiovascular Research Centre. Vol PhD. 2006: UNIVERSITY of GLASGOW; 2006:1-296. 65. Nishi H, Kimura A, Harada H, Koga Y, Adachi K, Matsuyama K, Koyanagi T, Yasunaga S, Imaizumi T, Toshima H, et al. A myosin missense mutation, not a null allele, causes familial hypertrophic cardiomyopathy. Circulation 1995;91:29112915.

66. Gotoda Y, Wakamatsu N, Kawai H, Nishida Y, Matsumoto T. Missense and nonsense mutations in the lysosomal alpha-mannosidase gene (MANB) in severe and mild forms of alpha-mannosidosis. Am J Hum Genet 1998;63:1015-1024.

Table 1: Main characteristics of the included studies

\begin{tabular}{|c|c|c|c|c|c|c|c|c|}
\hline Author & Year & Nationality & $\begin{array}{c}\text { Age } \\
\text { range } \\
\text { (year) }\end{array}$ & Gender & $\begin{array}{c}\text { Case } \\
(21-H T Z)\end{array}$ & $\begin{array}{c}\text { Control } \\
\text { (Mutation free) }\end{array}$ & $\begin{array}{c}\text { Mutation } \\
\text { Analyses } \\
\text { Method }\end{array}$ & $\begin{array}{c}\text { 17OHP } \\
\text { Measureme } \\
\text { nt Method }\end{array}$ \\
\hline Oriolo et al. & 2020 & Italy & $\begin{array}{c}\text { HTZ: } 22 \\
2 \pm 7.2 \\
\text { Control: } \\
24.0+9.2\end{array}$ & $\mathrm{~F}$ & $\begin{array}{l}15 \text { (PCOS } \\
\text { diagnosis) }\end{array}$ & $\begin{array}{l}32 \text { (PCOS } \\
\text { diagnosis) }\end{array}$ & $\begin{array}{c}\text { Sanger } \\
\text { sequencing }\end{array}$ & RIA \\
\hline Polat et al. & 2019 & Turkey & $\begin{array}{l}\text { Range } \\
18-45\end{array}$ & $\mathrm{~F}$ & $\begin{array}{l}14 \text { (PCOS } \\
\text { diagnosis) }\end{array}$ & $\begin{array}{l}40 \text { (PCOS } \\
\text { diagnosis) }\end{array}$ & $\begin{array}{c}\text { Sanger } \\
\text { sequencing }\end{array}$ & RIA \\
\hline $\begin{array}{c}\text { Grodnitskaya } \\
\text { et ai., }\end{array}$ & $2017^{+}$ & Russia & $\begin{array}{c}\text { HTZ: } \\
26.4 \pm \\
5.3 \\
\\
\text { Control: } \\
26.1 \pm \\
7.2\end{array}$ & $\mathrm{~F}$ & $\begin{array}{c}7 \text { (one of the } \\
\text { clinical androgenic } \\
\text { symptoms } \\
\text { (oligo/amenorrhea, } \\
\text { hirsutism or acne) } \\
\text { and/or elevation } \\
\text { of at least one } \\
\text { serum androgen.) }\end{array}$ & $\begin{array}{l}\text { 43(one of the } \\
\text { clinical } \\
\text { androgenic } \\
\text { symptoms } \\
\text { (oligo/amenorrhe } \\
\text { a, hirsutism or } \\
\text { acne) and/or } \\
\text { elevation } \\
\text { of at least one } \\
\text { serum } \\
\text { androgen.) }\end{array}$ & $\begin{array}{l}\text { ARMS, } \\
\text { MLPA }\end{array}$ & ELISA \\
\hline
\end{tabular}




\begin{tabular}{|c|c|c|c|c|c|c|c|c|}
\hline $\begin{array}{l}\text { Neocleous et } \\
\text { al. }\end{array}$ & 2017 & $\begin{array}{l}\text { Greek } \\
\text { Cypriot }\end{array}$ & $\begin{array}{l}\text { Not } \\
\text { stated }\end{array}$ & $\mathrm{F}$ & $\begin{array}{c}52 \text { (clinical } \\
\text { hyperandrogenism } \\
\text { ) }\end{array}$ & $\begin{array}{c}52 \text { (clinical } \\
\text { hyperandrogenis } \\
\mathrm{m})\end{array}$ & $\begin{array}{c}\text { Sanger } \\
\text { sequencing, } \\
\text { MLPA }\end{array}$ & RIA \\
\hline Settas et al. & $2013^{+}$ & Greece & $\begin{array}{c}\text { HTZ: } \\
23.4 \pm \\
5.4 \\
\text { Control: } \\
29.5+5.5\end{array}$ & $\mathrm{~F}$ & $\begin{array}{l}15 \text { (PCOS } \\
\text { diagnosis) }\end{array}$ & $\begin{array}{l}68(\mathrm{PCOS} \\
\text { diagnosis })\end{array}$ & $\begin{array}{c}\text { ARMS+ } \\
\text { Sanger } \\
\text { Sequencing }\end{array}$ & \\
\hline $\begin{array}{l}\text { Napotilano et } \\
\text { al. }\end{array}$ & $2011 *$ & Italy & $\begin{array}{l}\text { Not } \\
\text { stated }\end{array}$ & $\mathrm{F}+\mathrm{M}$ & $\begin{array}{l}161 \text { (relatives of } \\
\text { patients with } \mathrm{CAH} \\
\text { and } \mathrm{NCAH} \text { ) }\end{array}$ & $\begin{array}{c}73 \text { (relatives of } \\
\text { patients with } \\
\text { CAH and NCAH } \\
\text { and healty } \\
\text { volunteers) }\end{array}$ & $\begin{array}{c}\text { Southern } \\
\text { Blot } \\
\text { Multiplex } \\
\text { minisequenc } \\
\text { ing,LR-PCR } \\
\end{array}$ & \\
\hline $\begin{array}{c}\text { Costa- } \\
\text { Barbosa et al. }\end{array}$ & $2010^{*}$ & Brazil & $\begin{array}{l}\text { HTZ:23- } \\
\quad 62 \\
\text { Control: } \\
\text { 23-65 }\end{array}$ & $\mathrm{F}+\mathrm{M}$ & $\begin{array}{l}61 \text { (parents of } \\
\text { affected patients } \\
\text { with } 210 H D)\end{array}$ & $\begin{array}{l}27 \text { (healthy } \\
\text { volunteers) }\end{array}$ & $\begin{array}{l}\text { ARMS, } \\
\text { MLPA }\end{array}$ & LC-MS/MS \\
\hline Paris et al. & 2010 & France & $\begin{array}{c}\text { HTZ: } \\
6.8+0.7 \\
\\
\text { Control: } \\
6.7+1.3\end{array}$ & $\mathrm{~F}$ & 8 (PP diagnosis) & $\begin{array}{c}25(\mathrm{PP} \\
\text { diagnosis })\end{array}$ & $\begin{array}{c}\text { Sanger } \\
\text { Sequencing }\end{array}$ & RIA \\
\hline Bidet et al. & $2009 *$ & France & $\begin{array}{l}23.4 \pm 8.8 \\
\text { (range } \\
13-52 \text { ) }\end{array}$ & & $\begin{array}{l}211 \text { (relatives of } \\
\text { patients with } \mathrm{CAH} \\
\text { and } \mathrm{NCAH} \text { ) }\end{array}$ & $\begin{array}{c}36 \text { (relatives of } \\
\text { patients with } \\
\mathrm{CAH} \text { and } \\
\mathrm{NCAH} \text { ) }\end{array}$ & $\begin{array}{c}\text { Sanger } \\
\text { sequencing, } \\
\text { Southern } \\
\text { Blot, } \\
\text { RT-qPCR }\end{array}$ & RIA \\
\hline Admoni et al. & 2006 & Israil & $\begin{array}{l}\text { Not } \\
\text { stated }\end{array}$ & $\mathrm{F}+\mathrm{M}$ & $\begin{array}{l}\text { 24(PP and/or } \\
\text { hirsutism, and/or } \\
\text { premature } \\
\text { telarche) }\end{array}$ & $\begin{array}{l}43 \text { (hirsutism, } \\
\text { PP, precocious } \\
\text { puberty, } \\
\text { menstrual } \\
\text { irregularity) }\end{array}$ & SSOP & RIA \\
\hline $\begin{array}{c}\text { Bachega et } \\
\text { al. }\end{array}$ & 2000 & Brazil & $\begin{array}{l}\text { Not } \\
\text { stated }\end{array}$ & $\mathrm{F}+\mathrm{M}$ & $\begin{array}{l}13 \text { (precocious } \\
\text { pubarche, acne, } \\
\text { hirsutism and/or } \\
\text { menstrual } \\
\text { irregularities) }\end{array}$ & $\begin{array}{c}8 \text { (precocious } \\
\text { pubarche, acne, } \\
\text { hirsutism and/or } \\
\text { menstrual } \\
\text { irregularities) }\end{array}$ & ARMS & RIA \\
\hline $\begin{array}{c}\text { Dacou- } \\
\text { Voutetakis et } \\
\text { al. }\end{array}$ & & & $\begin{array}{l}\text { Not } \\
\text { stated }\end{array}$ & $\mathrm{F}+\mathrm{M}$ & $\begin{array}{l}18 \text { (premature } \\
\text { adrenarche) }\end{array}$ & $\begin{array}{c}26 \text { (premature } \\
\text { adrenarche) }\end{array}$ & $\begin{array}{l}\text { ARMS, } \\
\text { Southern } \\
\text { Blot }\end{array}$ & RIA \\
\hline Withcel et a & $1998^{*}$ & USA & $\begin{array}{l}\text { Not } \\
\text { stated }\end{array}$ & $\mathrm{F}+\mathrm{M}$ & $\begin{array}{l}28 \text { (relatives of } \\
\text { patients with } 21- \\
\text { hydroxylase } \\
\text { deficiency) }\end{array}$ & $\begin{array}{c}23 \text { (healthy } \\
\text { control and } \\
\text { relatives of } \\
\text { patients with } 21 \text { - } \\
\text { hydroxylase } \\
\text { deficiency) }\end{array}$ & ASOH,SSCP & RIA \\
\hline Witchel et al. & $1997 \mathrm{a}$ & USA & $\begin{array}{l}\text { Not } \\
\text { stated }\end{array}$ & $\mathrm{F}+\mathrm{M}$ & $\begin{array}{l}28 \text { (relatives of } \\
\text { patients with } \\
21 \mathrm{OHD})\end{array}$ & $\begin{array}{l}22 \text { (healthy } \\
\text { control and } \\
\text { relatives of } \\
\text { patients with } 21- \\
\text { hydroxylase } \\
\text { deficiency) }\end{array}$ & ASOH,SSCP & RIA \\
\hline Witchel et al. & 1997b\# & USA & $\begin{array}{c}\text { Not } \\
\text { stated }\end{array}$ & $\mathrm{F}+\mathrm{M}$ & 10 (PP diagnosis) & $\begin{array}{c}18(\mathrm{PP} \\
\text { diagnosis }) \\
\end{array}$ & ASOH,SSCP & RIA \\
\hline Witchel et al. & 1997b\# & USA & $\begin{array}{c}\text { Not } \\
\text { stated }\end{array}$ & $\mathrm{F}+\mathrm{M}$ & $\begin{array}{c}4 \text { (clinical } \\
\text { hyperandrogenism }\end{array}$ & $\begin{array}{c}10 \text { (clinical } \\
\text { hyperandrogenis }\end{array}$ & ASOH,SSCP & RIA \\
\hline
\end{tabular}




\begin{tabular}{|l|l|l|l|l|l|l|l|}
\hline & & & & & & $\mathrm{m})$ & \\
\hline
\end{tabular}

* shows the study included in the analysis group formed from asymptomatic heterozygous carriers and asymptomatic mutation free controls, ${ }^{+}$shows the study those only had basal 17 OHP levels. \# shows the same study used two times in the same analyses with two different data set. F: female, M: male, RIA; Radioimmunoassay, LC-MS/MS; Liquid Chromatography with tandem mass spectrometry, ELISA; Enzyme-linked immunosorbent assay, SSCP; Single-strand conformation polymorphism, ASOH; Allele-specific oligonucleotide hybridization, SSOP; Sequence-specific oligonucleotide probes, ARMS; Amplificationrefractory mutation system, MLPA; Multiplex ligation-dependent probe amplification, RT-qPCR; Quantitative polymerase chain reaction, LR-PCR: long range PCR, 21HTZ; CYP21A2 heterozygous, HTZ; heterozygous, PCOS; Polycystic ovary syndrome, $\mathrm{CAH}$; Congenital adrenal hyperplasia, NCAH; Non-classic CAH, PP; Premature pubarche.

Table 2: The cut-off value for predicting heterozygous individuals with standard dose synacthene stimulation test. SDSST: Standard dose synacthene stimulation test, AUC: Area under ROC curve, CI:Confidence interval

\begin{tabular}{|c|c|c|c|c|c|c|}
\hline SDSST & AUC & $95 \% \mathrm{CI}$ for $\mathrm{AUC}$ & $\mathbf{p}$ & Cut-off value & Sensitivity & Specificity \\
\hline Basal 17OHP symptomatic & 0.67 & $0.39-0.87$ & 0.279 & - & - & - \\
\hline Stimulated $17 \mathrm{OHP}$ symptomatic & 0.80 & $0.57-1.0$ & 0.034 & 13.41 & $\% 100$ & $\% 66.7$ \\
\hline Basal 17OHP asymptomatic & 0.68 & $0.33-1.0$ & 0.347 & - & - & - \\
\hline Stimulated 17OHP asymptomatic & 1.0 & $1.0-1.0$ & 0.009 & 10.48 & $\% 100$ & $\% 100$ \\
\hline
\end{tabular}

SDSST: Standard dose synacthene stimulation test, AUC: Area under ROC curve, CI:Confidence interval *ROC curve analysis from study-level data

Figure 1: Flow chart to illustrate the process by which articles were selected or rejected based on the inclusion and exclusion criteria of the study. 


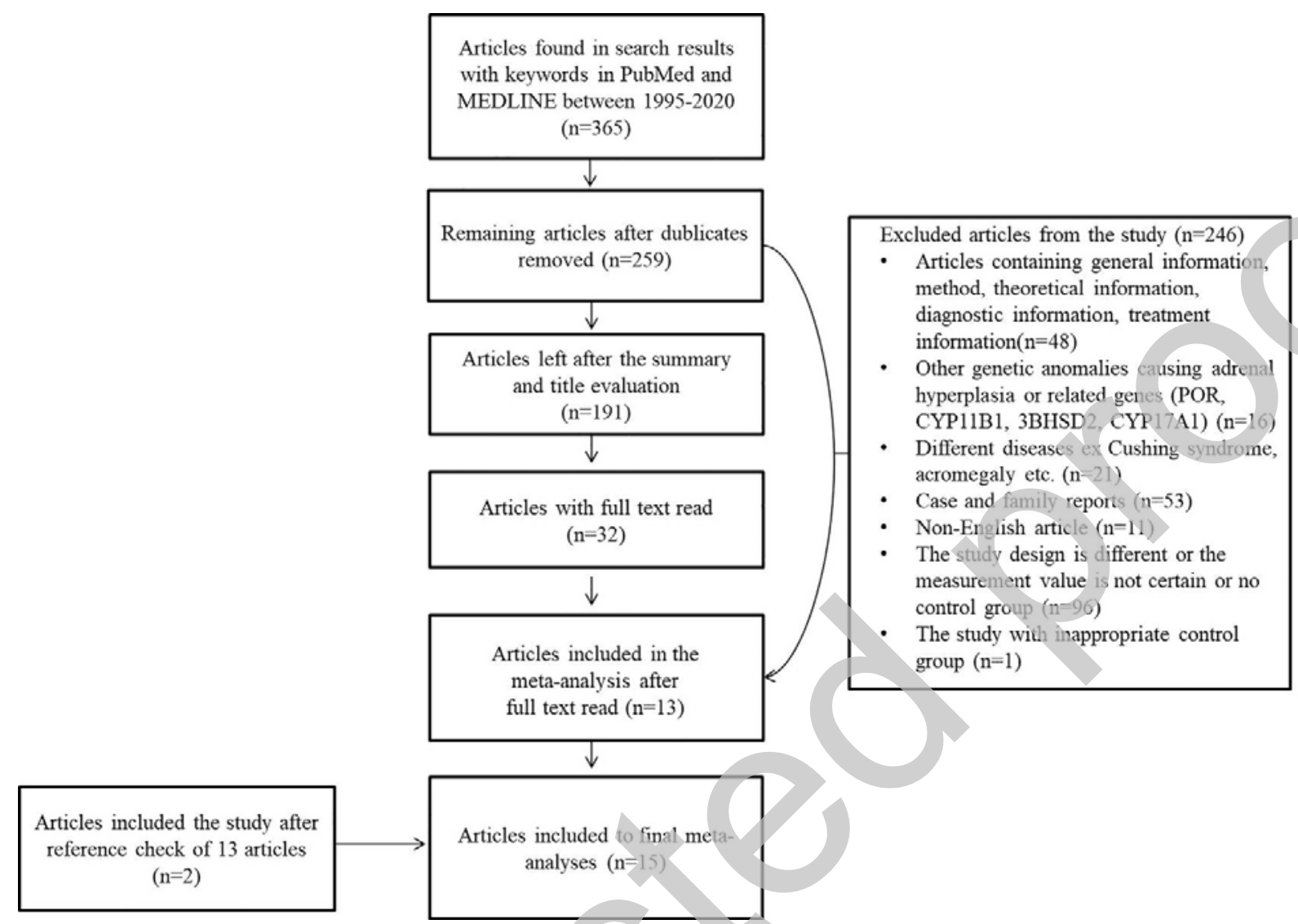

Figure 2: Forest plot of 17-hydroxyprogesterone response to standard dose synacthene stimulation test of symptomatic heterozygous vs. symptomatic mutation- free volunteers. *shows the same study used two times in the same analyses with two different data set. 


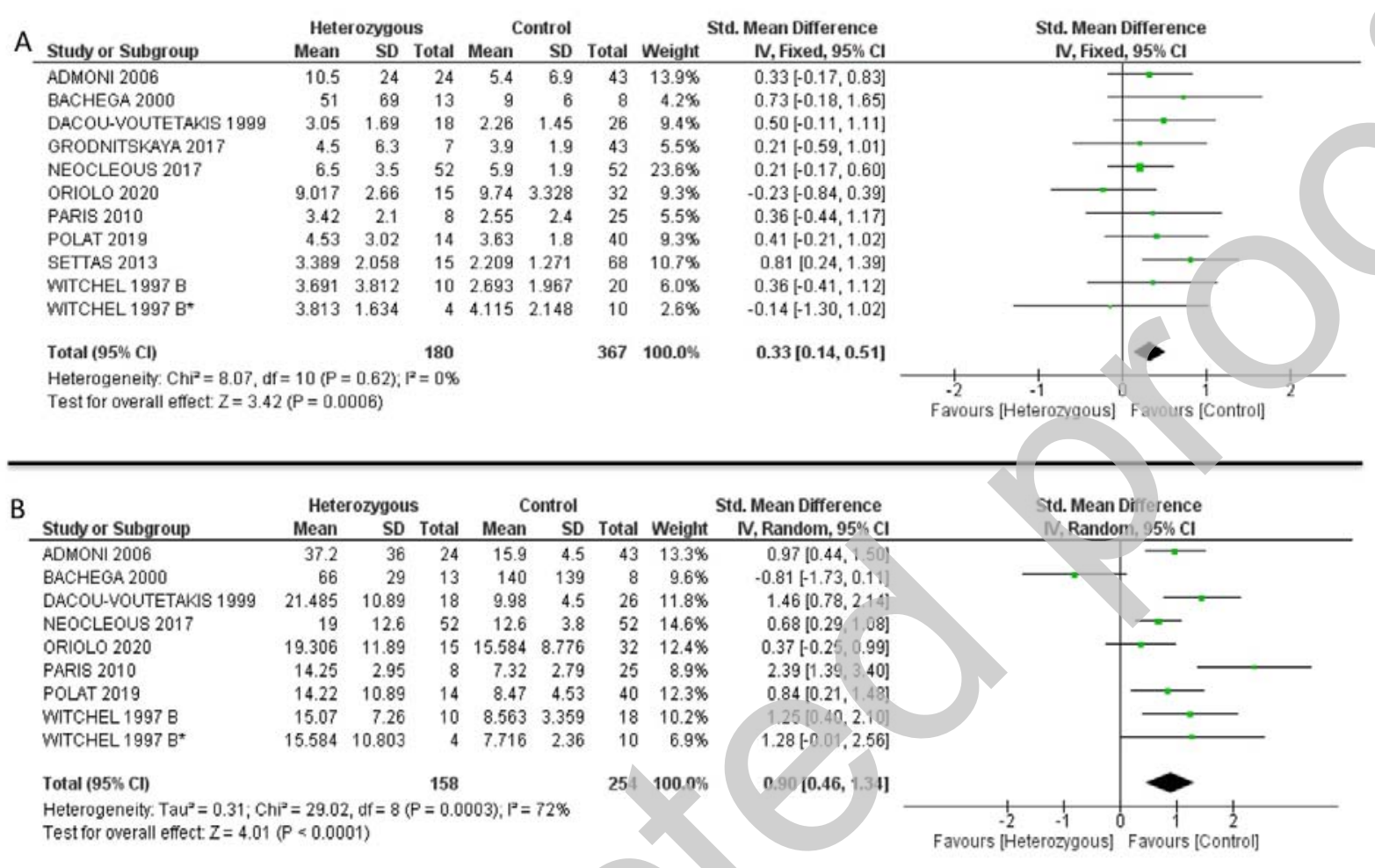

Figure 3: ROC-curve analysis for basal and stimulated 17-OHP levels in symptomatic and asymptomatic groups. A: Basal 17OHP levels of symptomatic heterozygous vs. symptomatic mutation-free volunteers B: Stimulated 17-OHP levels of symptomatic heterozygous vs. symptomatic mutation-free volunteers C: Basal 17-OHP levels of asymptomatic heterozygous vs. asymptomatic mutation-free healthy volunteers D: Stimulated 17-OHP of asymptomatic heterozygous vs. asymptomatic mutation-free healthy volunteers 

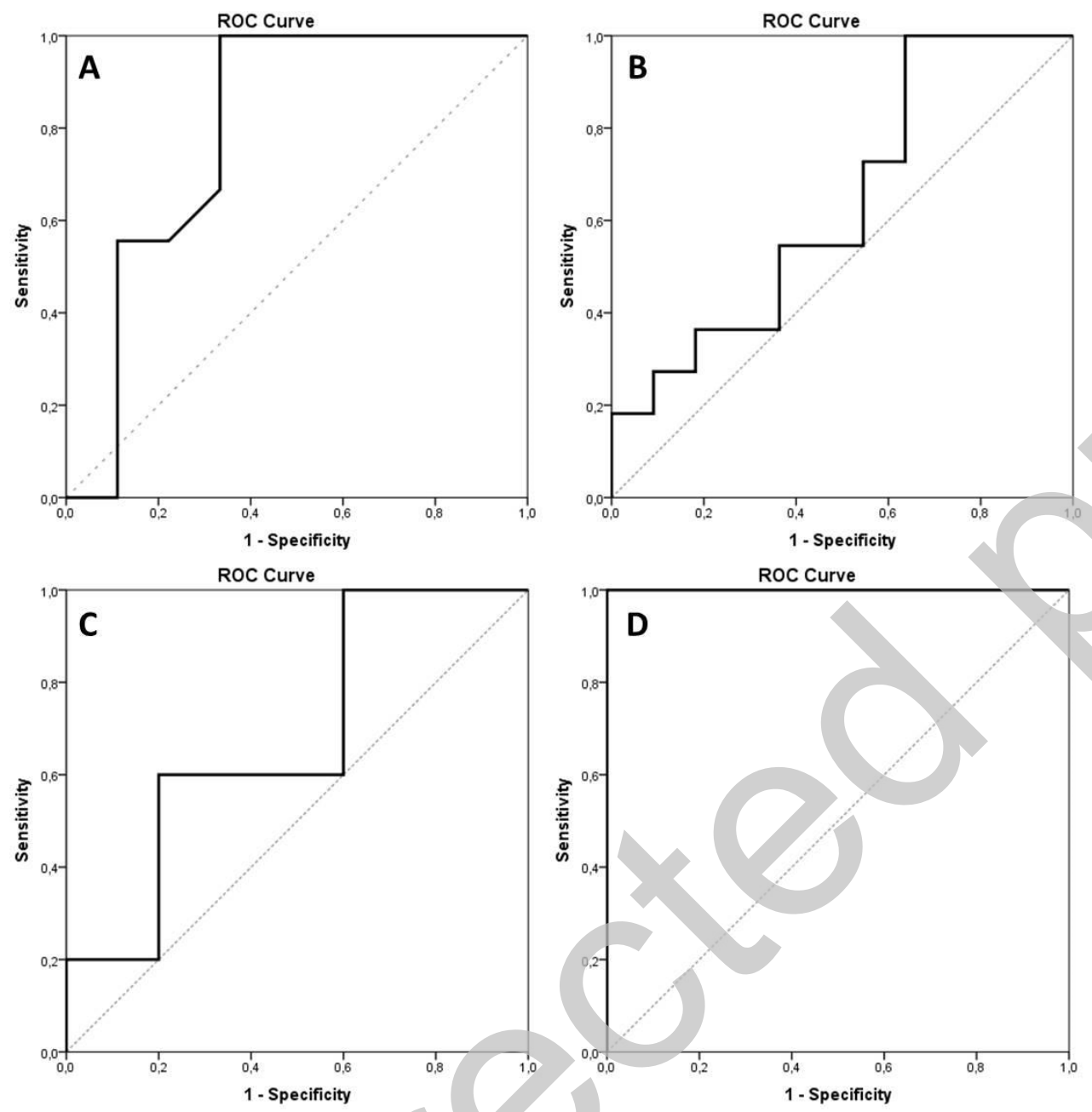

Figure 4: Forest plot of 17-hydroxyprogesterone response to standard dose synacthene stimulation test in asymptomatic heterozygous vs. asymptomatic mutation-free healthy controls. 


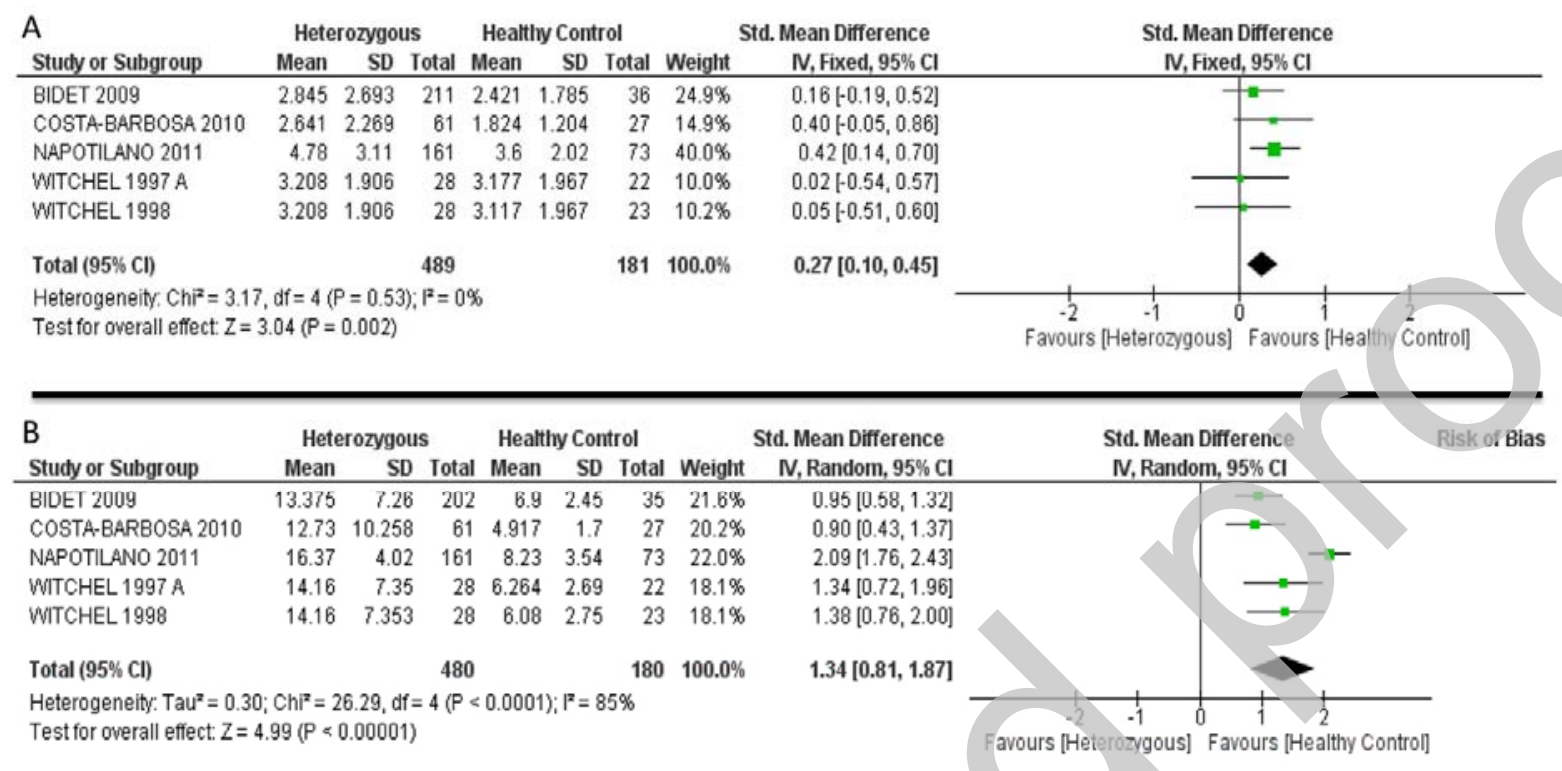

Figure 5: Box plot for median of basal and stimulated 17-OHP levels in symptomatic and asymptomatic groups 

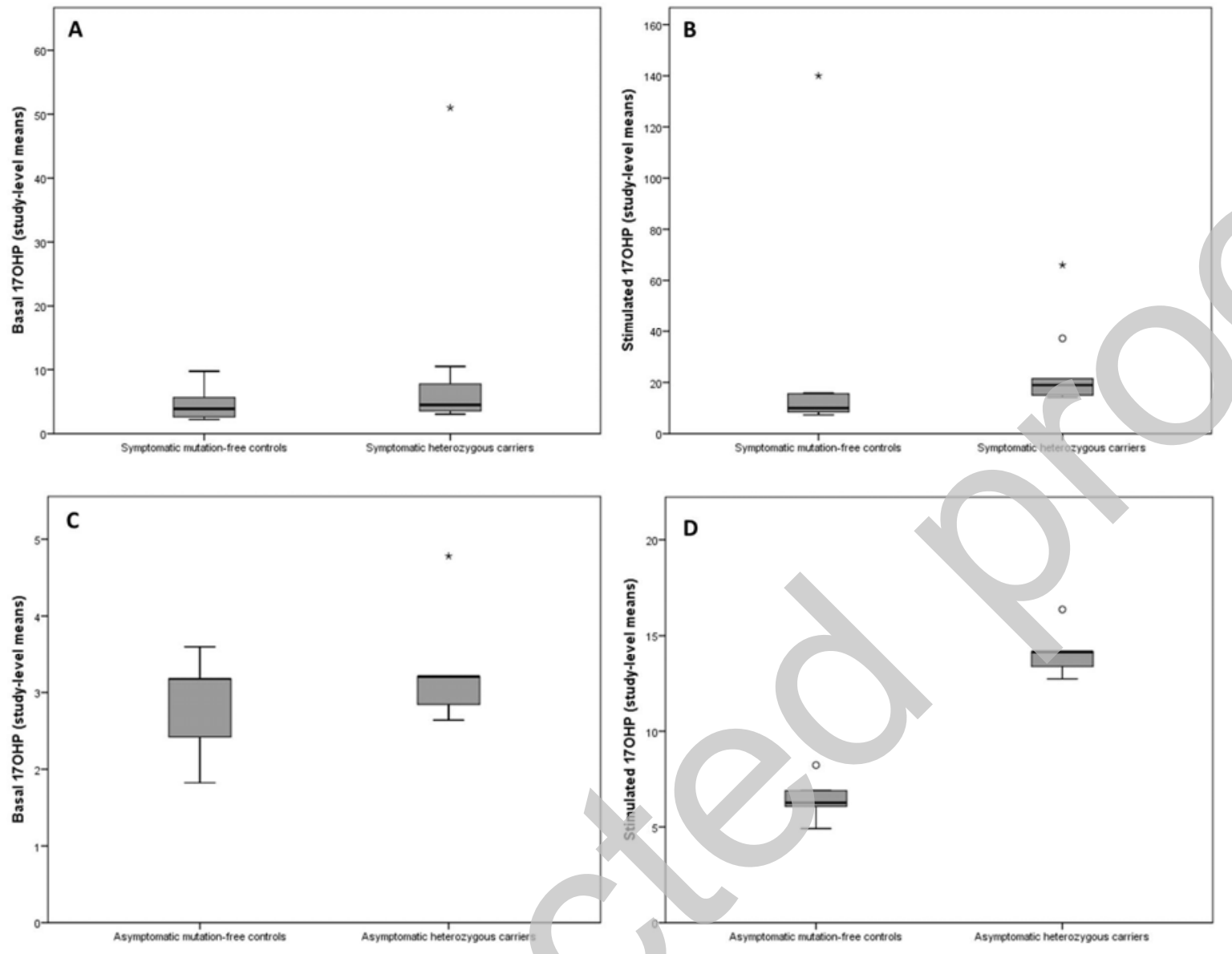

Figure 6: Funnel plots to detect publication bias of the meta-analysis. A: Basal 17-OHP levels of asymptomatic heterozygous vs. asymptomatic mutation-free healthy volunteers B: Stimulated 17-OHP levels of asymptomatic heterozygous vs. asymptomatic mutation-free healthy volunteers C: Basal 17-OHP levels of symptomatic heterozygous vs. symptomatic mutation-free volunteers D: Stimulated 17-OHP of symptomatic heterozygous vs. symptomatic mutation-free volunteers. The standardized mean difference (SMD) on the $\mathrm{x}$-axis is plotted against the standard error (SE) of the SMD on the y-axis. Symmetrical distribution of studies indicates the absence of publication bias. 

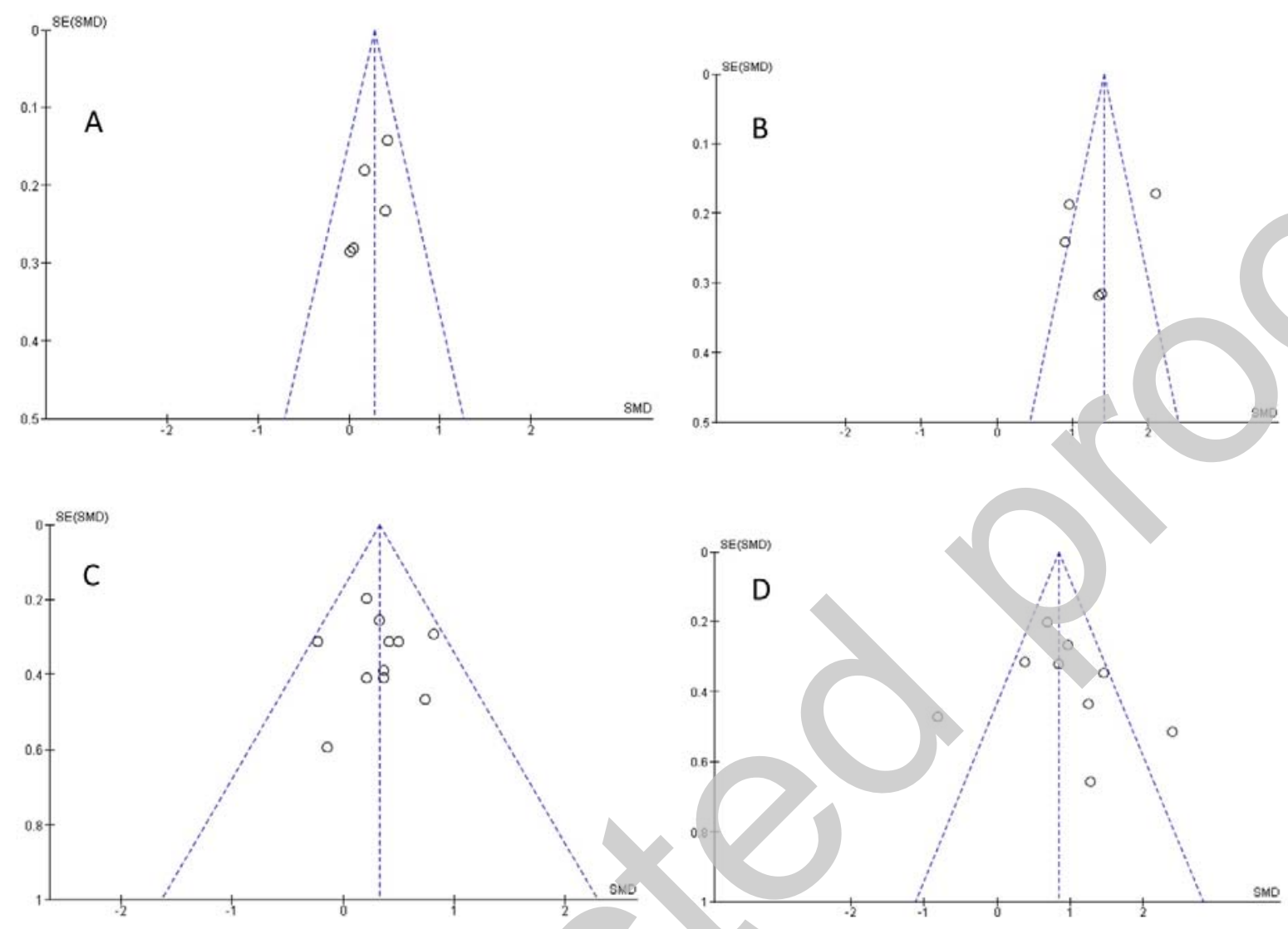